\title{
20 \\ Genotypic Association and Path Co-efficient Analysis in Ashwagandha [Withania Somnifera (L.) Dunal]
}

\section{S.B. CHAUDHARY, R.S. BAGUL AND S.S. DODAKE}

See end of the paper for authors' affiliation

Correspondence to :

\section{S.B. CHAUDHARY}

Medicinal and Aromatic Plants Project, Mahatma Phule Krishi Vidyapeeth, Rahuri, AHMEDNAGAR (M.S.) INDIA

\begin{abstract}
To study genotypic and phenotypic correlation and path co-efficient for seven characters were studied in 34 different local genotypes of ashwagandha. Results indicated that root yield was significantly and positively correlated associated among themselves except root branches with seed yield. Path co-efficient analysis showed highest positive direct and indirect effect of plant height and stem branches on root yield. Indirect effects of other component characters were high through plant height and stem branches on root yield. Selection for high plant height and stem branches appeared to be useful for improving root yield.
\end{abstract}

How to cite this paper : Chaudhary, S.B., Bagul, R.S. and Dodake, S.S. (2016). Genotypic Association and Path Co-efficient Analysis in Ashwagandha [Withania Somnifera (L.) Dunal]. Internat. J. Med. Sci., 9(2) : 81-83, DOI : 10.15740/HAS/IJMS/9.2/81-83.

\section{KEY WORDS :}

Correlation coefficient, Path coefficient, (Withania somnifera) 